\title{
回転する巻糸体周りの流れ之動力損失
}

（第 2 報）有限要素法による流れ場解析とその考察

\begin{tabular}{|c|c|c|c|c|}
\hline 金沢大学工学部 & 新 & 宅 & 救 & 徳 (会員) \\
\hline "I & 尾 & 田 & 十 & 八 \\
\hline ": & 山 & 崎 & 裕 & 之（会員） \\
\hline " & 仁 & 場 & 秀 & 樹 \\
\hline
\end{tabular}

\section{The Flow around the Rotating Pirn and Power Loss}

\section{Part 2: Flow Analysis by FEM and Considerations}

\author{
Sukenori Shintaku, Juhachi Oda, Hiroyuki Yamazaki, Hideki Banba
}

Faculty of Engineering, Kanazawa University, Kanazawa

\begin{abstract}
The flow around a pirn rotating at high speed was analysed and considered by using parameters as numbers of revolutions and pirn surface conditions.

The results obtained from this analysis were as followed:

1) The flow around the rotating pirn with the boundary conditions of numbers of revolutions and pirn surface conditions can be analysed.

2) The velocity vector of flow in the proposed analysis has good agreement with experiment results for the previous described conditions.

3 ) From the flow analysis by FEM (finite element method), we can learn contour of Stokes' stream function, vortexes and circumferential reverse flow which can't be easily obtained from experiment.
\end{abstract}

\section{摘 . 要}

(Received July 17, 1989)

目的 巻系体の回転数や表面状態をパラメーターとして, 高速回転する巻系体周りの流楊を有限要素法により解析して, こ の結果を先に発表している実験結果と比較，検討しながら考察する。

成果 本研究によって得られた結果を以下に示す。

1) 巻系体の回転数や表面状態の境界条件の扱いを含めて，巻系体周りの流れ場を解析することができた。

2）巻系体周りの速度ベクトル解析値は，前報の各条件下の実験結果と比較してほぼ一致した.

3) 流れ場解析結果から, 測定実験では容易に得ることのできない流れ関数や渦度の等値線及び円周方向の流れの逆流等を知 ることができだ。

(平成元年 7 月17日受理)

\section{1. 緒 言}

前報において著者ら”は，回転する巻系体周りの 流れ状態を可視化実験により定性的に観察した。 又, 定量的にはこれを実験的に求める手法を提案し て実験を行った。ささらに,この流れに伴う動力損失
をモーターの反力より測定し, .これと流れ状態から 求めた動力損失值との関係を考察した. そして実験 結果をあとに, 巻糸体からの流れの吹き出しを押さ え, かつ流れがスムースになるようなカバーを推定 し, 実際に試作, 設置して巻系体周りの流れと動力 損失の改善を図った。 
ところで，現在までに報告されている回転体周り の流れに関する研究は, 回転の対象体が円柱に限ら れたあのがほとんどであり，又，本実験のような高 速回転域の研究報告は数少ない。これは円柱以外の 形状の回転体を扱う時は, その周りの流れは極端に 複雑となり，この回転数域が高速になると流れの可 視化及び速度や圧力分布などの測定が難しくなるか らである. 又, 巻系体のような表面が䄉維で覆われ た物体を扱う際に，数値計算におけるこの表面上の 境界条件の取り扱いは特別な配慮が必要である。計 算上においても，このような回転体の場合には，時 間に対するその特性が周期的であり，よって計算に おいて何回か収束する計算結果のいずれが正しいの かという点で, 計算結果が真に安定したかどうかを 判定しにくい欠点がある.

そこで本報では，最近では色々な分野で使用され るようになった有限要素法を用いて，上述した数値 計算における境界条件の取り扱い方等を含めて, 高 速回転する巻糸体周りの流れ場を解析する，又，同 時に，流れ場の速度べクトル図や実験では容易に得 ることができなかった流れ関数及び渦度の等值線等 を同時に出力させ，巻系体周りの流れを前報とは別 の観点から考察する．そして，この結果と前報の測 定結果を比較，検討することにより，巻系体の表面 状態の違いによる境界条件の扱い方や前報で設置し たカバーの妥当性等を考察する.

\section{2. 流れ場解析の有限要素法理論}

巻系体周りの空気流れを有限要素法によって解析 する．対象が回転体であるので，座標系は図 1 に示 すような巻系体の自軸を中心軸にとった円筒座標系 を用いる．仮定として，扱う流れの速度には円周方 向 $(\theta$ 方向) の変化はないものとする.これより主と して解析及び結果は，半径方向 $(r$ 方向）之軸方向 ( $z$ 方向) の座標で形成される面を中心に行う. 又, 本解析範囲内では，扱う流体は非圧縮性流体とす る.

数値計算法は，時間に関する逐次計算法を用い る. 逐次計算法による繰り返し計算は, 運動方程式 と連続の式を基礎式として用いる。そこして，これら の式をストークスの流れ関数（以下，流れ関数） $\phi^{2)}$ と渦度 $q$ 及び円周方向速度成分 $V_{\theta}$ によって変形さ せた，渦度の式及び渦度方程式を時間的に準陰的な スキームに置き換えて用いる。そして，これらの $\phi$ と $q$ 及び $V_{\theta}$ の空間方向への離散化には Galerkin

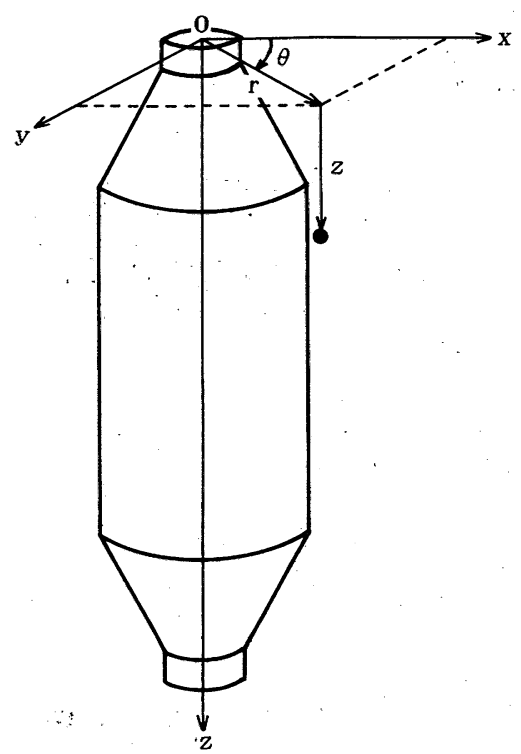

困 1 座標系

法を用いた。 $\phi$ で表した $V_{r}, . V_{z}$ の式を以下に示す

$$
V_{r}=-\frac{1}{r} \frac{\partial \psi}{\partial z} \quad \text { (1) }, \quad V_{z}=\frac{1}{r} \frac{\partial \dot{\phi}}{\partial r}
$$

一連の流れをフローチャートにして図 2 に示す. 図中の右肩の添え字は夕イムステップを意味する. この流れに沿って各ブロックを簡単に説明すると, 最初は渦なし流れ（ポテンジャル流れ）功出発 （ブロック 1)する，そして，わずかずつ時間を増分 させたタイムステップ（ブロック10）ごとに，この 流れ場に渦度の式（ブロック 2) と渦度方程式（ブ ロック 4) 及び $\theta$ 方向の運動方程式（ブロック 6) によって, $\phi$ と $q$ 及び $V_{\theta}$ を求める: 境界上の $q$ 及び $V_{\theta}$ は，隣接する節点の $\phi$ と $q$ 及び $V_{\theta}$ をティラー展 開した式に代入して求める。これより境界条件は, $\phi$ と $q$ 及び $V_{\theta}$ をタムステップごとにそれぞれの 方程式に与える（ブロック $3 ， 5$ )。ここで，計算中 のある流速が与えた周速の最大值を越えた場合を発 散したと判定する. 発散しないで, $q$ 及び $V_{\theta}$ の時間 に関する変化率が十分小さくなった時に準定常な流 れとみなして計算を打ち切り（ブロック 7,8 ）, 巻 系体周りの粘性流体の流れ特性として速度ベクトル や流れ関数及び渦度の等值線等を得ることができる (ブロック 9).

\section{3．計算モデルと境界条件}

巻系体周りの流れ場の解析に用いたメッジュデー 夕を図 3 に, 又, 流れの速度場を動力損失の点から 


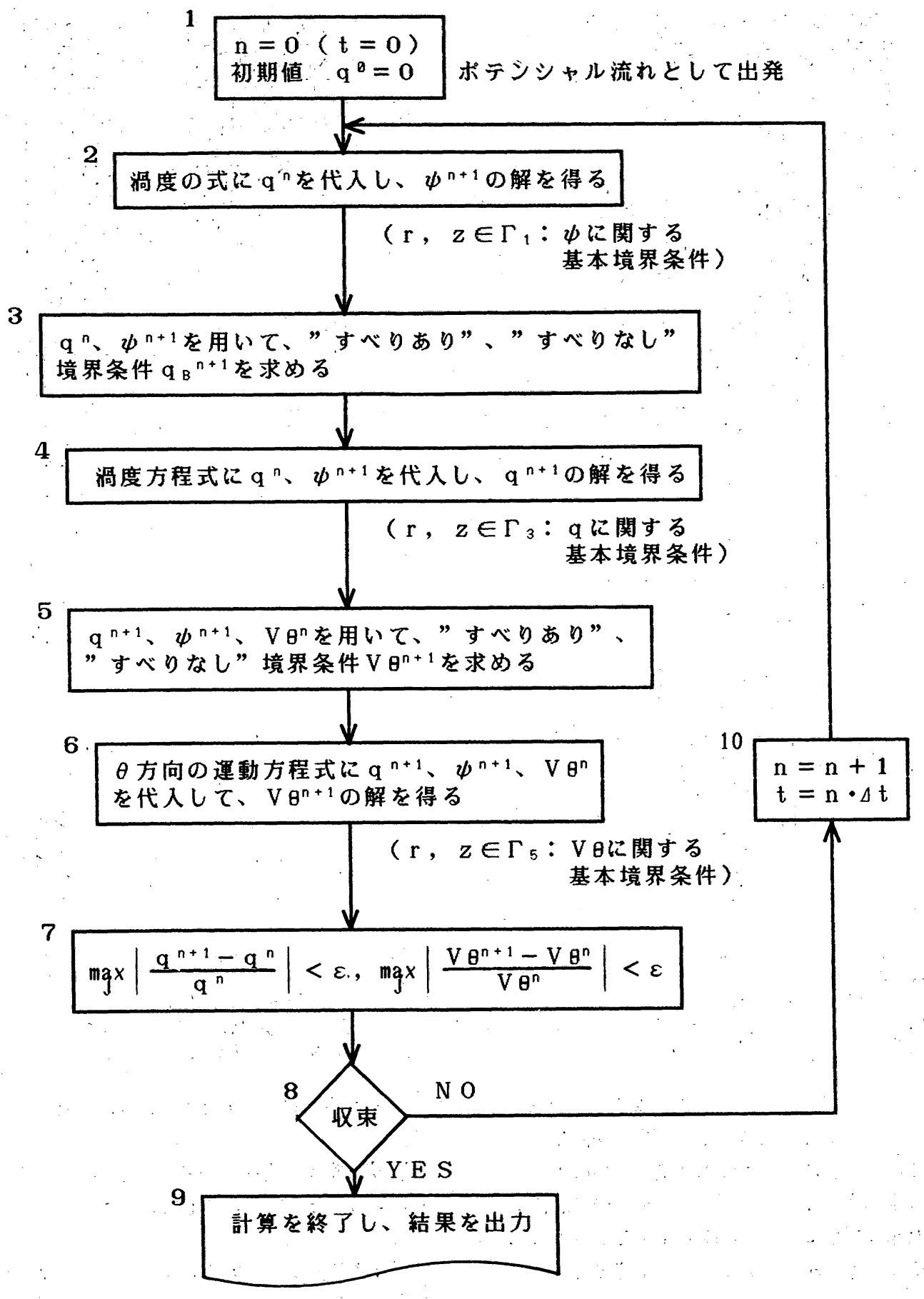

図2 回転体周りの流れ場解析のフローチャート

改善する目的で設置したカバー付き巻糸体周りの流 れ場解析のメッシュデータを図 4 に示す: 実験によ り巻系体表面から $200 \mathrm{~mm}$ を越えたところでは流 れの速度変化はほとんどないことを確認しているた
め, 図のように $500 \mathrm{~mm} \times 180 \mathrm{~mm}$ の範囲をメッシ 二分割した.メッシュは, 節点数が208節点, 要素数 が348要素から成り, 重要な巻系体近辺については 細かい分割を行った。なお力バ一付きの流れ場に 


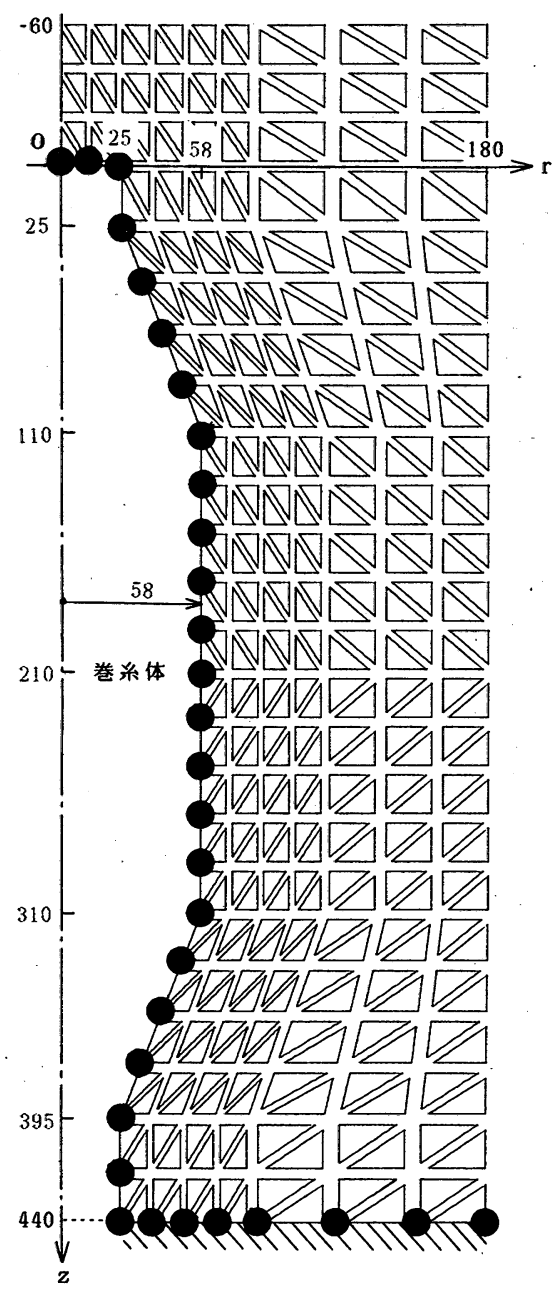

図 3 巻系体周りの流れ場解析のメッシュデー夕（単 位: $\mathrm{mm}$ )

(節点数208, 要素数348)

: $V_{\theta}$ の境界値 いい:すべりなし

巻系体と平板のかど点: $q=0$

は，カバー部のメッシュを消去して199節点，316要

素とした. 又，同図には与えた境界条件も同時に示 した.ここで, 巻系体表面の速度境界層の厚さやこ の付近の流れ状態は, 巻系体表面の周速や表面状態 及びその他の要因によって随時変化すると考えられ るが，ここでは原則的に次の 3 条件を境界条件とし て与える。

境界条件 1。巻糸体の表面で流れの主方向となる $\theta$ 方向に周速度を与える (図 3,4 中の○印の点), 又，カバー付きの場合にはカバー表面では $V_{\theta}=0$ である (図 4 中のカバー部のの印の点).

境界条件 2. 綿巻糸体の場合, 毛羽周りの渦によ

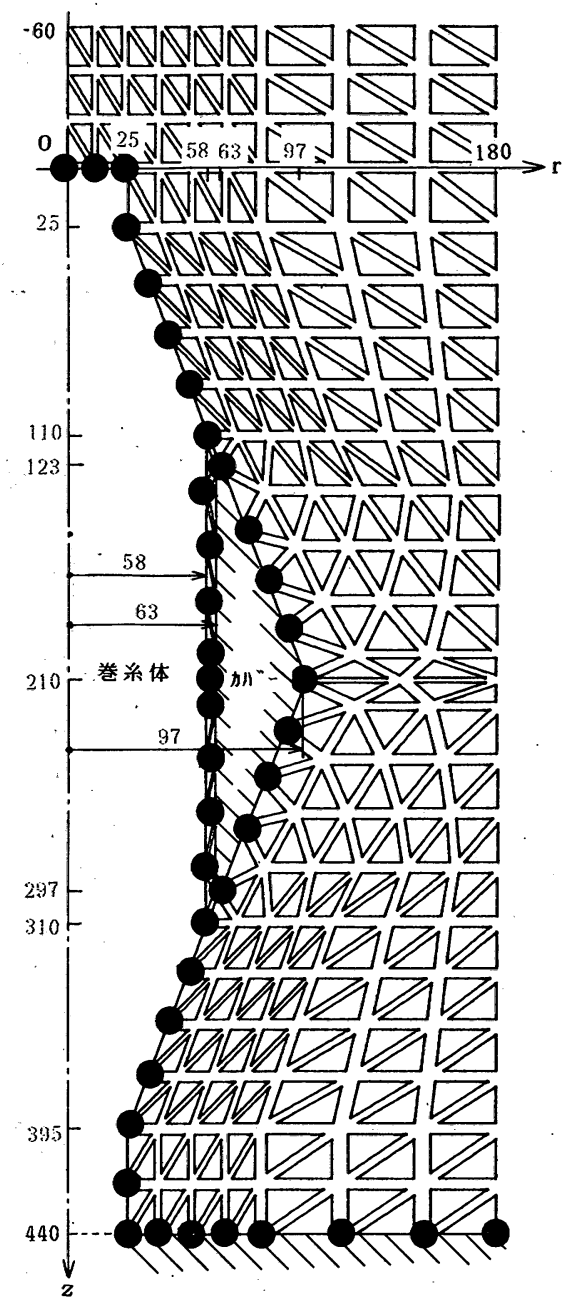

図 4 カバー付き巻系体のメッシュデータ（単位： $\mathrm{mm})$

(節点数 199 , 要素数 316$)$

○： $V_{\theta}$ の境界值いい：すべりなし

巻系体と平板のかど点 : $q=0$

る損失や毛羽同士の相互干渉は考慮しないものとす る.

境界条件 3. 巻糸体を支える底面を $\phi=0$ の基準 面とする，そしてこの底面ではすべりはないあのと する.

以下各条件について説明する. 条件 1 について, 巻糸体の表面がなめらかな場合には巻系体の表面の $V \theta$ として巻糸体の半径 $r$ に角速度 $\omega$ を乗じた周速 度 $(r \cdot \omega)$ を与える. しかしながら, 綿巻系体の様 に綿系の毛羽により表面が粗い場合は，これを取り 扱う際に図 5 のように毛羽流㣗に対して直角に置か れた円柱と仮定する。これより，ある要素内の毛羽 


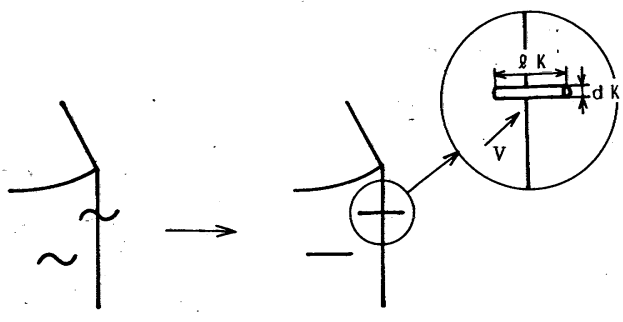

図 5 毛羽のモデル化

に作用する空気抗力 $F_{k}$ を次式より求める.

$$
F_{k}=C_{D} \cdot \rho \cdot V^{2} \cdot d_{k} \cdot l_{k} / 2
$$

ここで $C_{D}$ は空気抗力係数であり, $d_{k}$ 及び $l_{k}$ は巻系 体表面のある要素の毛羽の直径と全長である. 毛羽 直径は $0.01 \mathrm{~mm}$ として, この值は巻系体の表面に おいて一定とする. 毛羽長さと毛羽数の関係は, 綿 系の毛羽長分布図である図 6 より求められる。この 毛羽測定には東レ製光電式毛羽計測装置を用いた. なお同図において, 毛羽長さ 0 における毛羽数とは 系表面上で測定される毛羽数を累積した值である. よって, その数は系表面で最大となるので, この位 置を系表面と定義する. いま, 巻系体表面に巻いた 19.7 tex の綿糸の毛羽長分布の関係を片対数グラフ 上で近似すると,

$$
\log N_{k}=-0.5 \cdot d H_{k}+2.7
$$

$$
\left(N_{k}: \text { 本 } / \mathrm{m}, d H_{k}: \mathrm{mm}\right)
$$

を得る. この関係式の $N_{k}$ を図 6 の縦軸から分かる

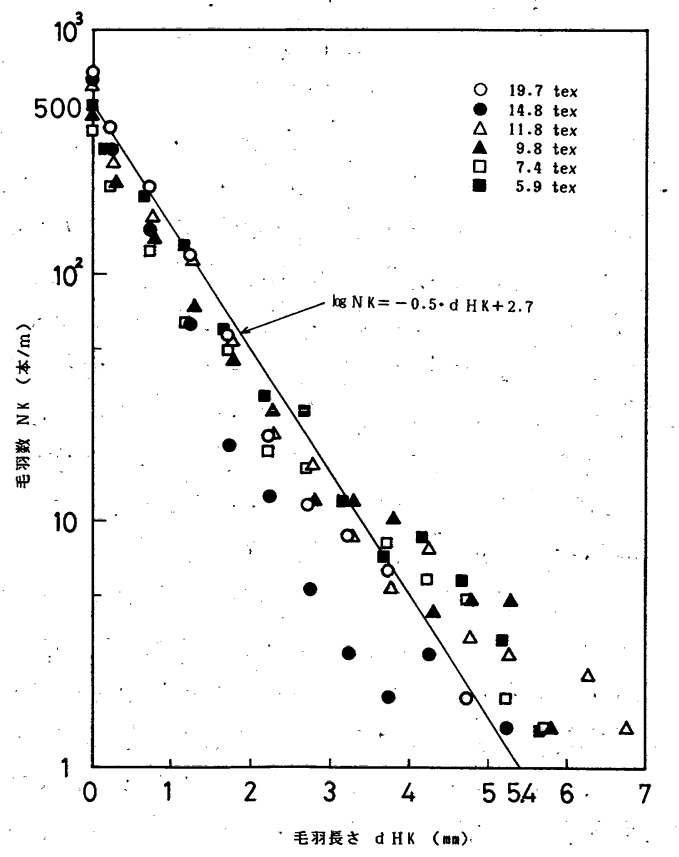

図6 綿系の毛羽長分布図
ように，1本から500本まで積分することにより，1 $\mathrm{m}$ 当たりの毛羽の全長 $H_{k}$ が分かる.

$$
\begin{aligned}
H_{k} & =\int, d H_{k}=\int_{1}^{500}\left(5.4-2 \cdot \log N_{k}\right) d N_{k} \\
& =430 \mathrm{~mm} / \mathrm{m}
\end{aligned}
$$

例えば, この值が意味しているのは, 19.7 tex の綿 系 $1 \mathrm{~m}$ 当たりに $1 \mathrm{~mm}$ 長の毛羽が430本あると考え てあよい数値である.この值に巻系体表面の要素長 さを乗ずることによって, その要素の毛羽の全長が 分かる.一方, $d_{k}$ に比して $l_{k}$ は非常に大きいので, 毛羽の抗力係数 $C_{D}$ は $l_{k} / d_{k}=\infty$ の時の係数である $C_{D}=1.20$ を用いる. 又, (3)式内の流速 $V$ には巻系 体表面の周速度を代入する. そして巻糸体表面に接 する要素扨において, $\theta$ 方向の運動方程式の外力成 分の項に，(3)式より算出した $F_{k}$ を要素ごとに加算 した方程式によって有限要素解析を行う. 又, カバ

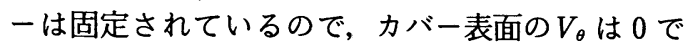
ある.

次に条件 2 については, 綿巻系体の場合には綿糸 表面に毛羽があるために表面が粗く, 毛羽同士のか らみ合いがあったり, 又, この毛羽周りに二次的な 渦流れが発生していると考えられる。しかしなが ら, 毛羽周りの渦損失や毛羽同士の相互干渉はここ では考慮しないすのとする。

最後に条件 3 については，巻系体を支える底面は $r$ 方向に無限に広く表面がなめらかな固定平板を想 定し, ゆえにここでの流体の出入りやすべりはない あのとして $\phi=0$ 及びすべりなし条件 ${ }^{3}$ を代入した。 又, 巻系体とこの平板のかど点には $q=0$ を代入し た.

ここで計算に用いた準陰的なスキームは，陽的な スキームに比して計算は速くなるが, レイノルズ数 （粘性力に対する慣性力の比）が大きくなると計算 が不安定になる傾向がある. そこで本解析では, 各

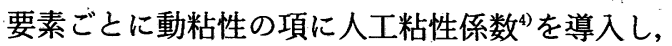
又, Courant 数 ${ }^{5}$ による時間増分を十分小さくする ことによって数值計算を安定させながら計算を行っ た. Courant 数を以下に示す.

$$
\text { Courant 数 }=\frac{U \cdot \Delta t}{S}<1
$$

ここで $U$ は代表速度を表し，ここでは巻糸体表面 の周速度を代入する. 又 $\Delta t$ は時間増分量, $S$ は三角 形要素の最小边長さを表す。そしてこの式を満たす ように $\Delta t$ を決定する. 


\section{4. 解析結果及び考察}

カバーなしである図 3 のモデルにおける巻系体周 りの各方向の速度成分の前報の実測値と解析した理 論値を上下に対比させて, 半径 $(r)$ 方向にういては 図 7 に, 円周 $(\theta)$ 方向については図 8 に, 軸 $(z)$ 方

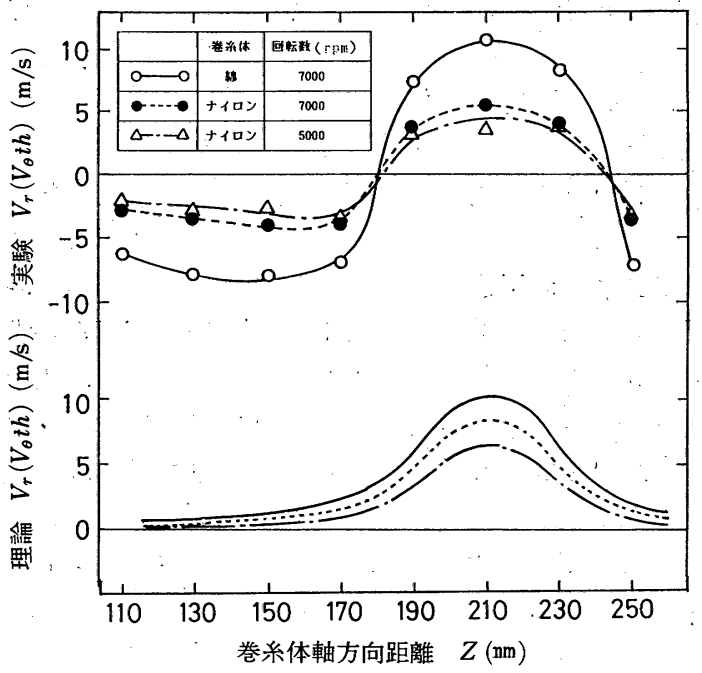

図 7 巻系体周りの半径方向速度成分

(半径方向距離 $r=68(\mathrm{~mm})$ )

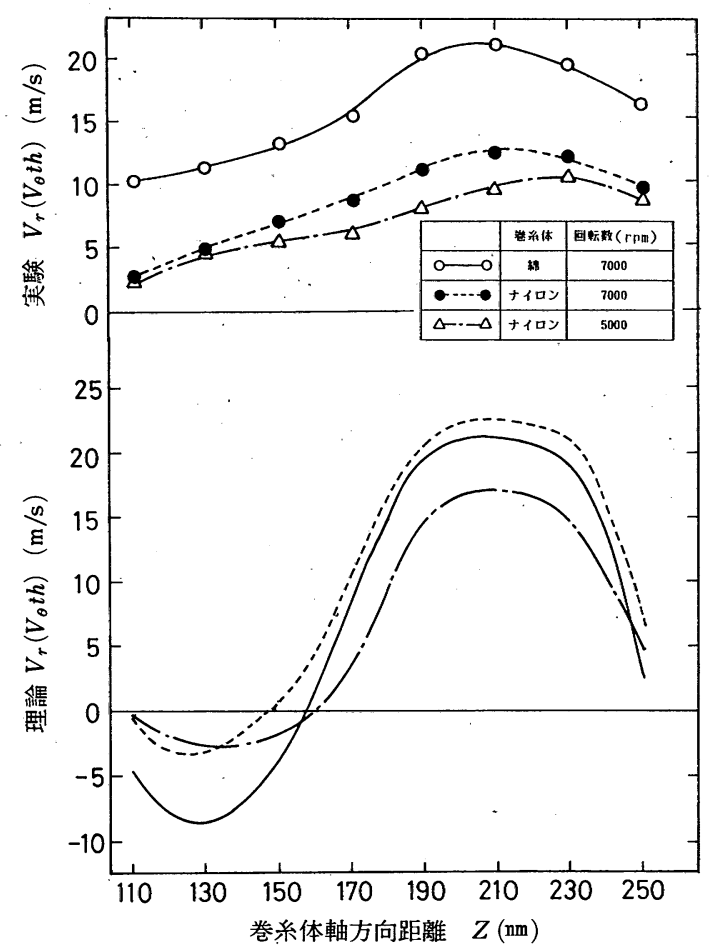

図 8 巻系体周りの円周方向速度成分 (半径方向距離 $r=68(\mathrm{~mm})$ )

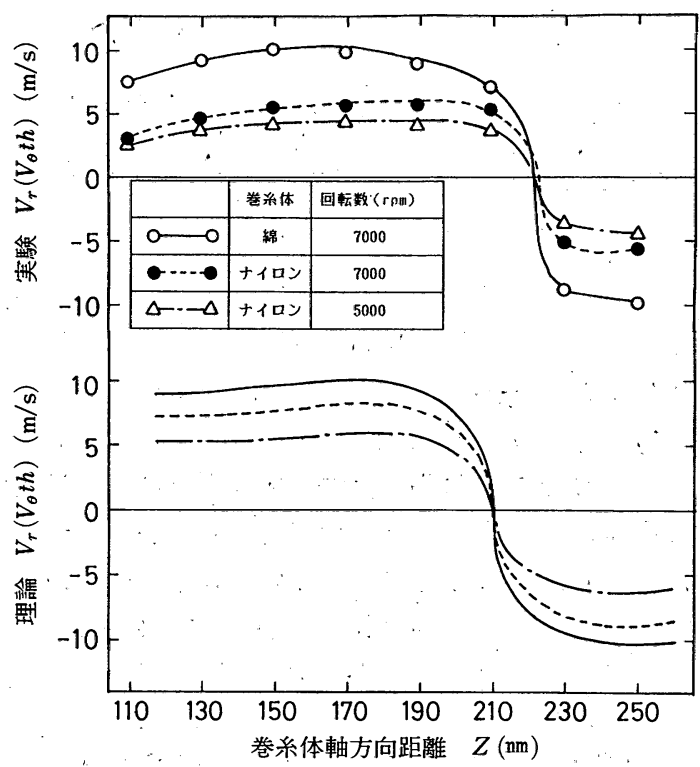

図 9 巻系体周りの軸方向速度成分 (半径方向距離 $r=68(\mathrm{~mm})$ )

向にういては図 9 に示す，又；同時にこれらの図か ら, 巻系体の表面状態及び回転数の違いによる各速 度成分の特性を読み取ることができる，それでは， まず図 7 に注目しょう. 半径方向の吹き出し流は, 実験, 理論の両者とあ巻系体の中央部である $z=$ $210 \mathrm{~mm}$ で最大となり，その大きさむほぼ等しい. ただ， 実験値は円柱部の端部で $V_{r}$ が負となってい ることから, 吸い込み流れが認められたが, 理論值

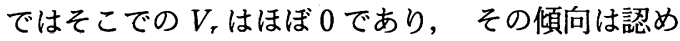
られなかった。これは, 数值計算において考慮した のは連続の理論による吹き出しと吸い込みの流量関 係の釣り合いのみであり，これだけでは巻系体回転 によって表面に生ずる，速度境界層内の流れがうま く表現されなかったためと考えられる. 次に図 8 に おいて, 理論の綿巻系体の $V_{\theta}$ がナイロン巻系体の それより小さくなった．回転数が同じであれば巻系 体表面の $V_{\theta}$ は同じであるのに対して， $V_{\theta}$ の逆流值 ( $V_{\theta}$ の負の値) は綿巻糸体の方が大きい.このため, 巻系体表面付近は $V_{\theta}$ の正流, 逆流が $r$ に対して交 互に発生しており，この間を平均した計算点の綿巻 糸体の $V_{\theta}$ はナイロン巻糸体のそれに比して小さく

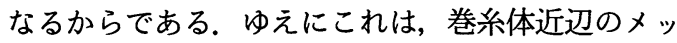
シュ分割の精度の問題であり, 本来の綿巻糸体の理 論值はナイロンのそれに重なるか，それよりわずか に大きくなるものと考えられる，又，ナイロン巻系 体の場合で, 理論值は実験值よりも大きい傾向を示 
しているが，これは巻系体表面から $10 \mathrm{~mm}$ 付近は $r$ 方向に対する $V_{\theta}$ の速度差は非常に大きく, 例えば $r$ が $1 \mathrm{~mm}$ 違うと大きい時で $3 \mathrm{~m} / \mathrm{s}$ も違うので, この 差は実験值の測定誤差と考えられる. 又, 理論では, 円柱部の端部で $V_{\theta}$ が負となっていることから，回 転とは逆方向の流れの存在が予測される。寒験にお いてす $V_{\theta}$ の逆流は認められたがその点の測定值が 不安定であり, しかもその逆流の検出が瞬間的であ るるので; 測定時間を十分にとると結局データとして この逆流は検出されなかった，これは図10に示すよ うに, 実験ではこの付近の $r$ 方向に対する $V_{\theta}$ の速 度差が大きいのに対し，これを測定するセンサー部 (球直径 $10 \mathrm{~mm}$ ) が大きかったために，この逆流を 検出できなかったものと考えられる. 又, このせん 断流は巻系体に近いことああって, 流れに多大の損 失を与えていると考えられる. しかしながら，後に 示す速度べクトル図から分かるようにカバーを設置 することにより，カバー部は巻系体円柱部の流れ場 の逆流発生筒所に位置しているので, カバーを設置 することで逆流発生箘所は減り, 又, 発生したとし てもこの逆流の最大值は設置していないものに比し て小さくなる. 一方, 図 9 において $z$ 方向の流れの 衝突位置は実験, 理論とあ巻系体の中央であり, そ の速度分布あ又ほとんど一致していることが認めら れる、ただカバーを設置すれば，巻系体中央部での 流れの衝突はほとんどなくなることす後の結果から 分かる.

図 7〜9より, 本実験の範囲内ではいずれの場合 あ回転数より表面状態による要因が速度に大きく影 響することを示している，又，これらの結果は各条 件に対して, 実験, 理論の両者ともほぼ一致してい ることから，境界条件の考え方を含めて本手法は巻

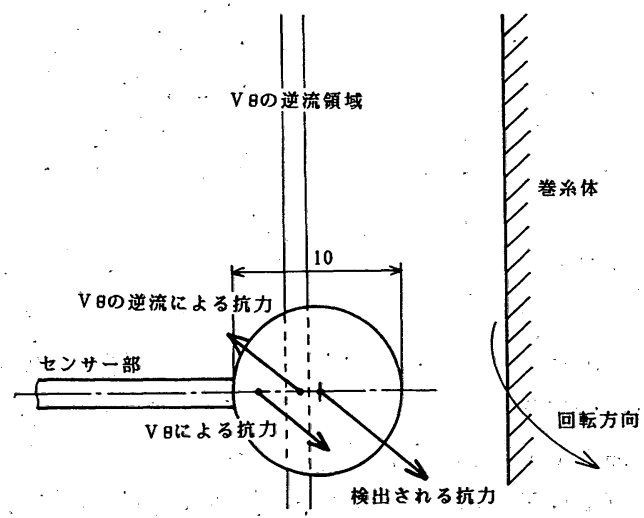

図10 実験で逆流を検出できない理由
糸体周りの流れ場をよく解析しているといえる.

以上の 3 つの解析例の結果とカバー付きの場合の 結果を含めて, 動力値及び収束した計算回数を表 1 に示す. 計算全般において，カバーなしの場合はす べて1,800回を越えたところで収束したが，カバー 付きの流れの場合では計算回数が極端に少なくなり 収束がはやい.これは，カバーを設置することで大 きな流速の出現のない流れ状態となったためと考え られる. 又, ·巻糸体の表面がなめらかな場合には計 算動力値は実際の動力値にほとんぞ一致する。この ことは逆に, ナイロン巻系体はその表面が十分にな めらかであることを意味している。しかしながら， 表面が粗い綿巻系体の(c)の場合には計算動力値は実 際のそれよりあ低い値を示す。このように，高速な 空気流に対して，あらゅる形状や方向を示す毛羽を モデル化することは大変難しく，流れ場を考察する と綿巻糸体においておよその解析はできたといえ る.

次に, 図 7〜9 分かりやすく $r-z$ 平面において ベクトル表示し，さらにカバー付きのこの種の結果 を含めて図11に示す:ここで左図は実測した速度べ クトル図である. 又, 本解析から同時に得られた の等值線を図 $12 に, q$ の等値線を図 13 及び $V_{\theta}$ の等 值線を図14に示す.こここに各図の(a)〜 (d)は表 1 に同 じである，速度べクトル図及び $\phi$ の等值線図である 図11と図12から全体的にいえることは, 巻系体付近 の空気は巻系体上下部のテーパー部から吸い込まれ て, 巻糸体中央の円柱部加ら吹き出している. 各条 件においてもこの流れ状態は同じであり, 巻糸体の 表面状態や回転数によって流速の絶対値のみが大き くなる. $q$ の等值線である図13より, 渦の発生位置 (巻系体表面全体) や渦度の大きな位置 (巻糸体の中 央部付近）は, カバーなしのすべての場合において 同じであり,この位置の渦形を何かで置き換えるこ とによりこの渦による流れの損失をなくすことがで きる. 渦度の大きい位置の円柱部の渦は, 前報のよ うなカバーで置き換えができるが，テーパー部のカ バーは実際問題において難しいと考えられる. 図14 の $V_{\theta}$ の等值線をみると, 円柱部においては $V_{\theta}$ の逆 流は考察したが, それ以上に巻糸体のテーパー部で これが最大となっていることから, 渦度の問題も含 めてテーパー部に何らかの対策が必要かもしれな い.ここで, 巻系体周りの流れの改善箇所を探るた めに，巻系体を $z$ 方向に 5 分割してここに表面が粗 い異種の系を各部分に巻き付けた 7 種類のモデルに 

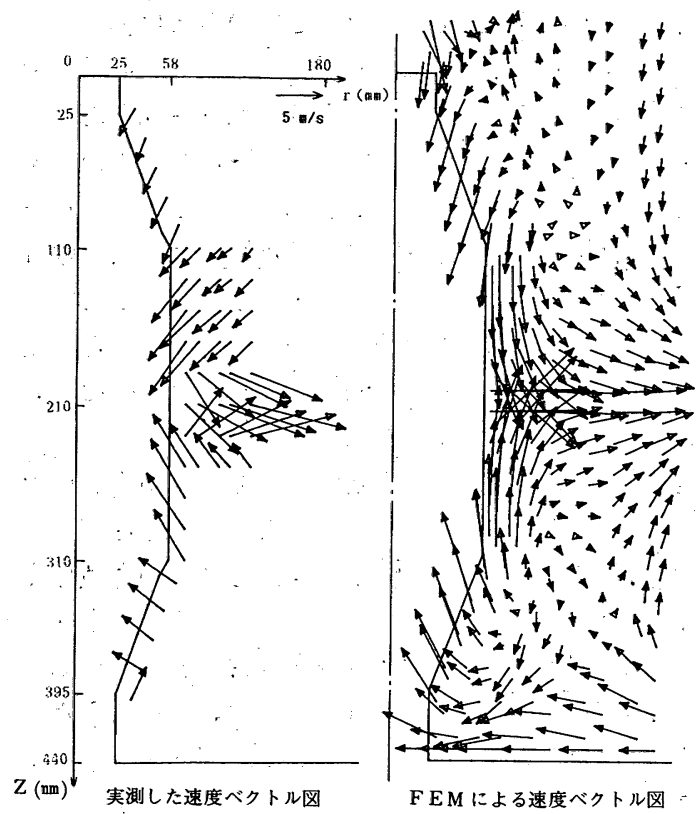

図11(a) 流れ場の $r-z$ 平面の速度べクトル図 （ナイロン巻系体，7000 rpm）
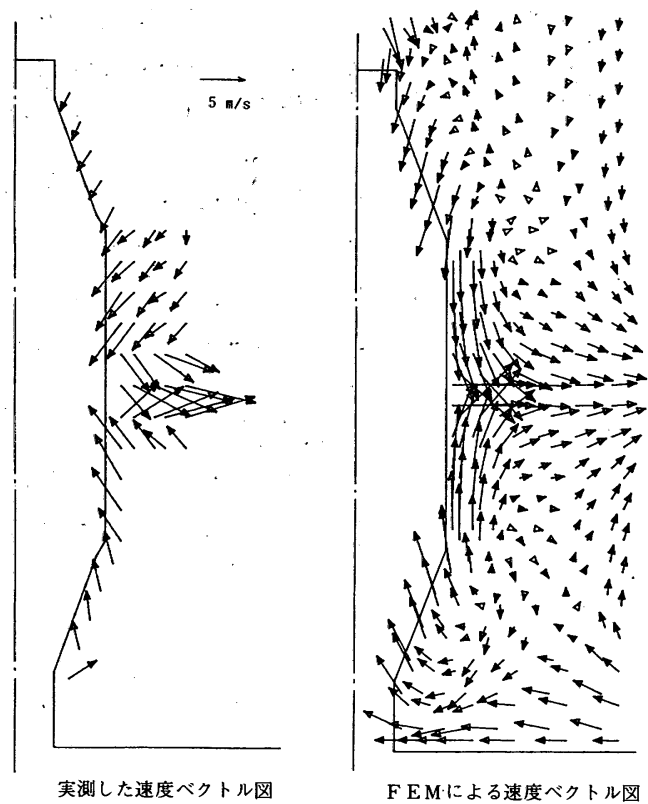

.図11(b) 流れ場の $r-z$. 平面の速度ベクトル図 （ナイロン巻系体，5000 rpm）

おける消費動力値を表 2 に示す．右にあるモデルほ ぞ消費動力は大きくなっている。これから読み取れ るように，動力に大きく影響している部分は，吸い 込みよりも吹き出し部分であることがはっきりと分 かる.これは吸い込み部分では，表面を粗くしてい
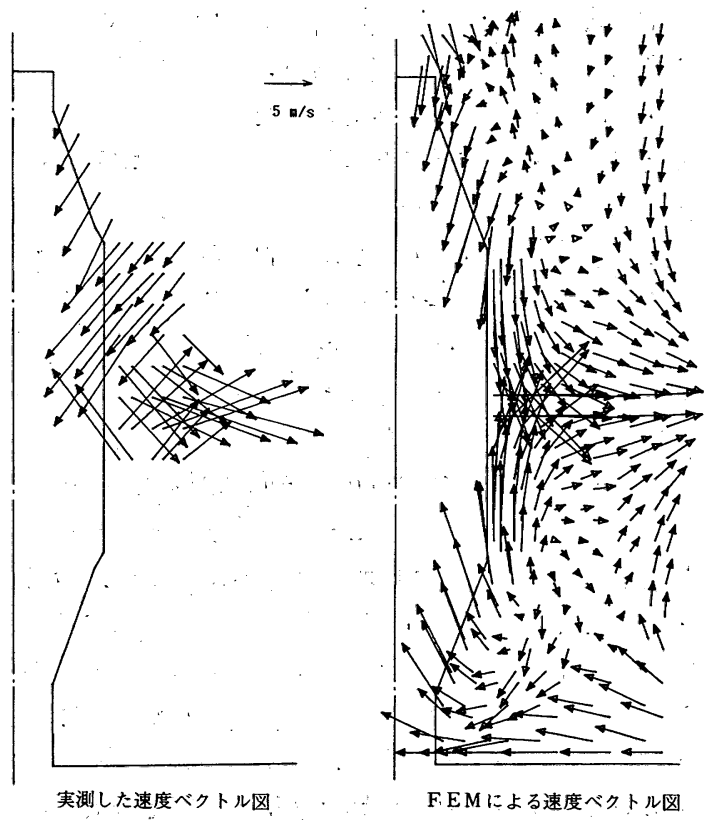

図11(c) 流れ場の $r-z$ 平面の速度ベクトル図 （綿巻系体， $7000 \mathrm{rpm）}$

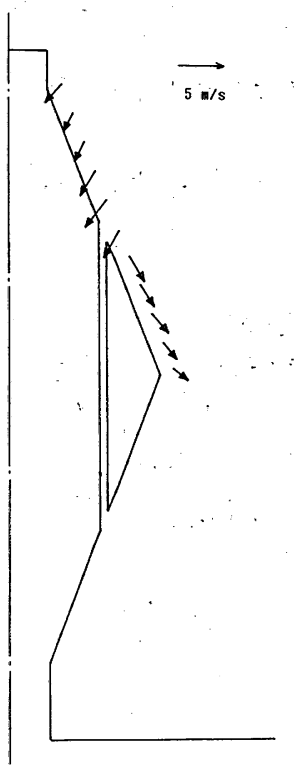

実測した速度ベクトル図

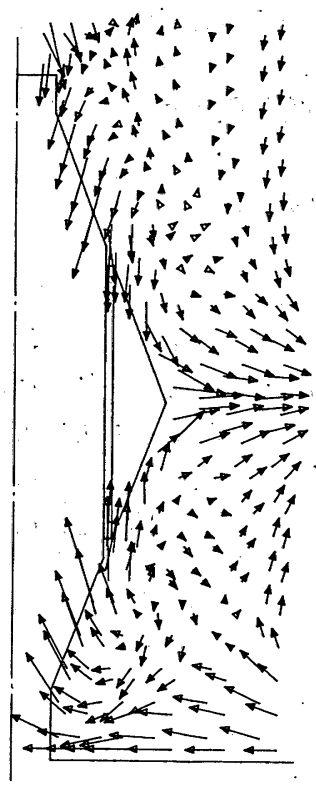

F EMによる速度ベクトル図 図11(d) 流れ場の $r-z$ 平面の速度ベクトル図 （ナイロン巻系体， $7000 \mathrm{rpm}$ ，カバー付き）

る毛羽は吸い込み流により巻系体側へと押し付けら れるのに対して, 吹き出し部分ではこの毛羽が引っ 張られて，これが管内流れでいうと管壁の突起物の ような存在となり，その分円周方向の流れ抵抗を大 きくするために損失動力が大きくなっているのであ 


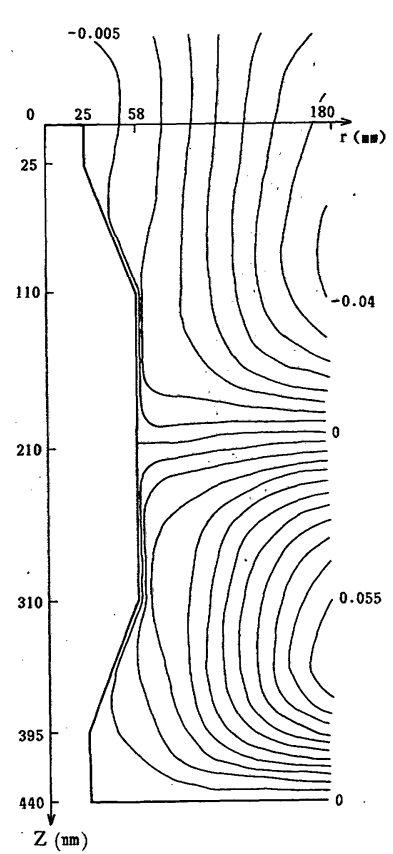

(a) ナイロン巻系体, $7000 \mathrm{rpm}$

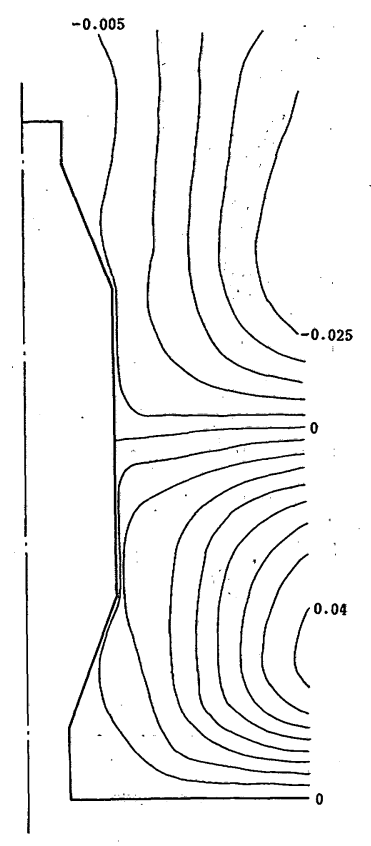

(b) ナイロン巻杀体, 5000rpm

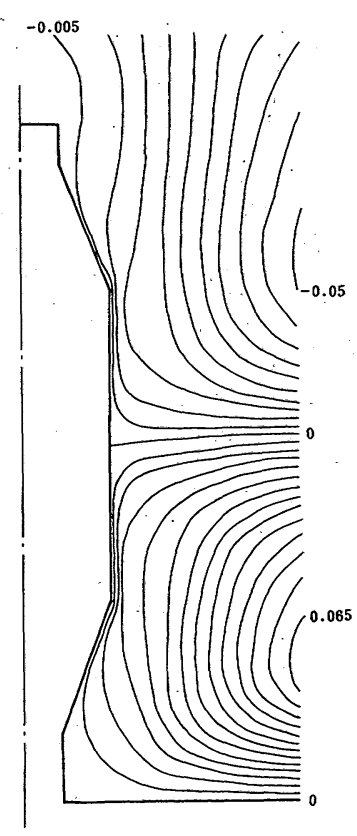

(c) 綿巻系体, $7000 \mathrm{rpm}$

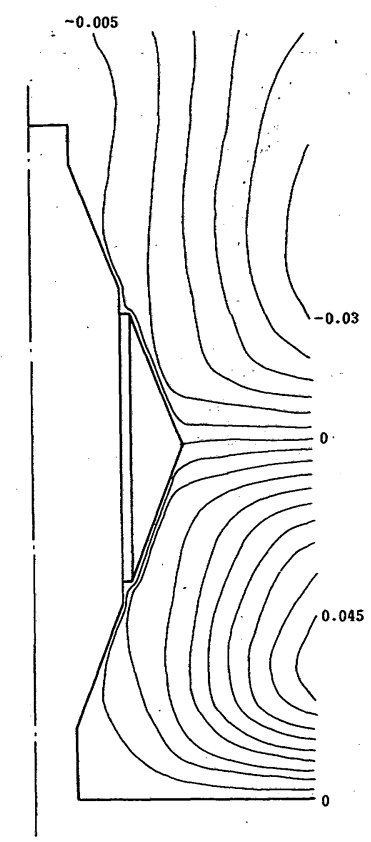

(d) ナイロン巻糸体, 7000rpm, カバー付き

図12 FEM から得られた $\psi$ の等值線（単位: $\mathrm{m}^{3} / \mathrm{s}$ ) （等值線の間隔 $0.005 \mathrm{~m}^{3} / \mathrm{s}$ )

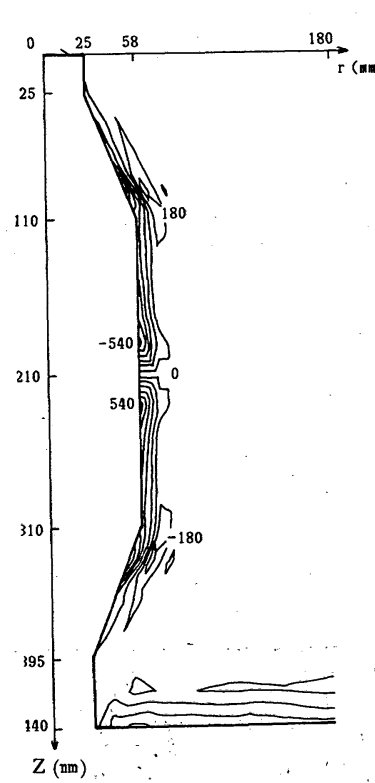

(a) ナイロン巻䒺体, 7000rpm

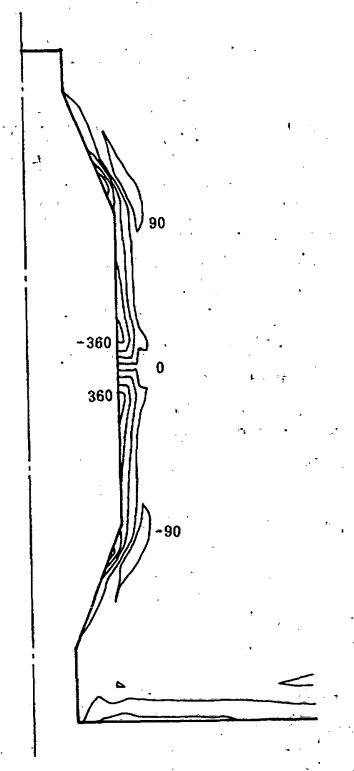

(b) ナイロン巻采体, $5000 \mathrm{rpm}$

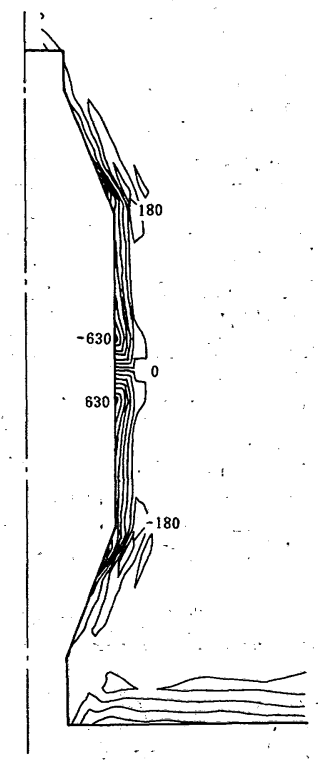

(c) 綿巻糸体, $7000 \mathrm{rpm}$

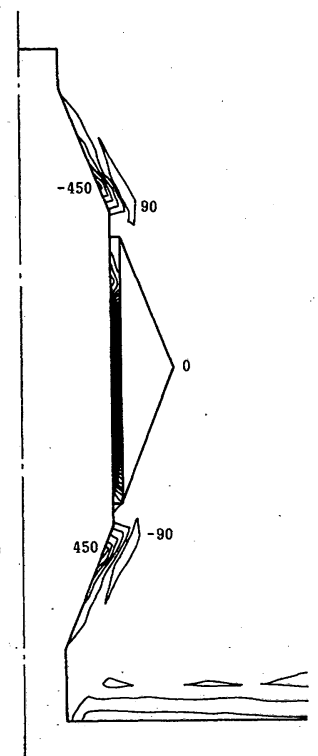

(d) ナイロン巻糸体, 7000rpm, カバー付き

図13 FEM から得られた $q$ の等値線 (単位: $1 / \mathrm{s}$ ) (等值線の間隔 $90 \mathrm{l} / \mathrm{s}$ )

る. この実験から，渦及び $V_{\theta}$ の逆流で問題となっ たテーパー部は吸い込み部であるから，動力的には さほど影響しないと思われる。 むしろそれよりあ，
円柱部の吹き出し流れ及び $z$ 方向の流れの衝突をう まく制御し，又は緩和するような方向でカバーを設 計した方がよいと考えられる。 そういったことも含 


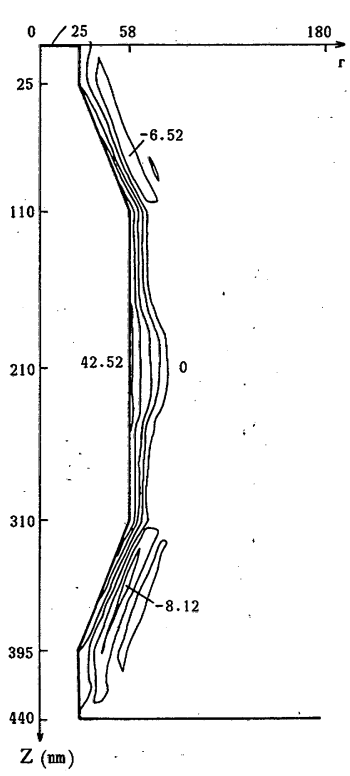

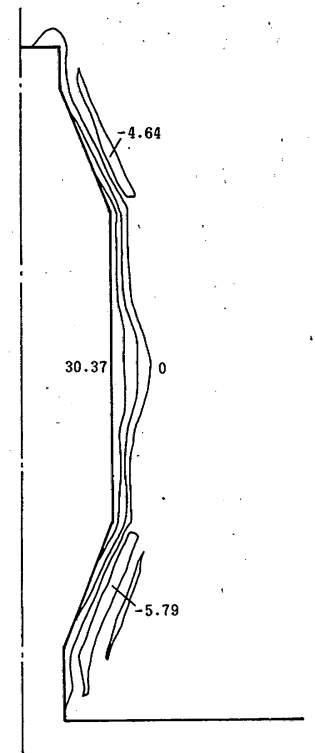

(b) ナイロン巻系体, $5000 \mathrm{rpm}$

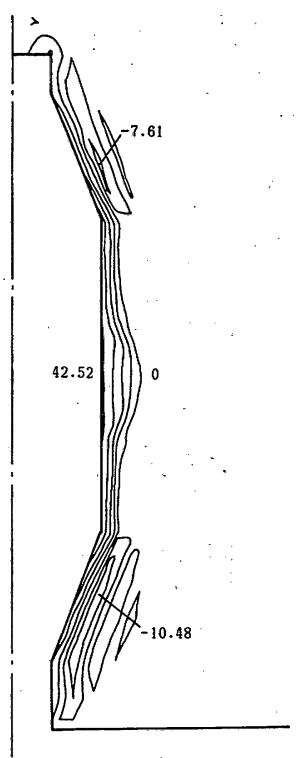

(c) 綿巻采体, $7000 \mathrm{rpm}$

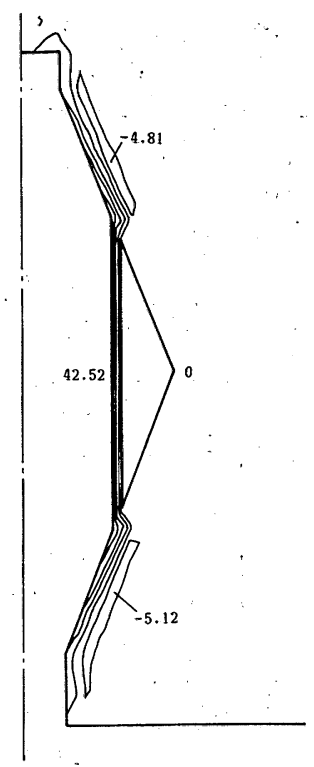

(d) ナイロン巻糸体, 7000 rpm, カバー付き

図14 FEM から得られた $V_{\theta}$ の等値線（単位： $\mathrm{m} / \mathrm{s}$ ) (等值線の間隔 $8 \mathrm{~m} / \mathrm{s}$, 負の値は $V_{\theta}$ の逆流の最 大値を示す)

表 1 測定した動力值と計算及び前報の実験から求めた動力値の比較

\begin{tabular}{cc|c|c|c|c}
\hline \hline \multicolumn{2}{c|}{ (単位はW) } & $(\mathrm{a})$ & $(\mathrm{b})$ & $(\mathrm{c})$ & $(\mathrm{d})$ \\
\hline 測 定 動 力 值 & 21.05 & 8.43 & 80.01 & 16.34 \\
\hline 計 算 動 力 值 & 21.00 & 7.72 & 34.69 & 13.05 \\
$(\mathrm{)})$ 内計算回数 & $(1828)$ & $(1829)$ & $(1857)$ & $(1602)$ \\
\hline 実 験 動 力 值 & 12.95 & 6.05 & 60.65 & 12.24 \\
\hline
\end{tabular}

※表内の各動力值及び $(\mathrm{a}) \sim(\mathrm{d})$ の意は次の通りである

測定動力值一モーターの反力より求めた動力値

計算動力値一本解析より得られた流れ状態から求めた動力值

実験動力值一実験により得られた流れ状態から求めた動力値

ここで，測定及び実験動力值は前報の值を用いた。

(a)一試料：ナイロン巻系体, 回転数: $7,000 \mathrm{rpm}$

(b) 一試料：ナイロン巻系体, 回転数：5,000 rpm

(c) 一試料：綿巻系体, 回転数: 7,000 rpm

(d) 一 ( a )のカバー付き

また (d)については, 13.05 Wの内 10.91 Wは巻系体とカバー間の

せん断流れによる損失動力である.

表 2 部分巻パーンの実際動力（W)

\begin{tabular}{c|c|c|c|c|c|c|c|}
\hline \hline \\
$(\mathrm{rpm})$
\end{tabular}

※白 部：ナイロン巻糸体 斜線部：ナイロン粗糸巻糸部 
めて, 前報のカバーは動力的にみてよい結果を生ん だあのと思われる.

以上の流れ場観察から, 巻系体の定性的な流れ状 態や渦の発生位置が糸種や回転数によらずほぼ同じ であることから, 巻系体周りのカバーを設計すると きは巻系体の形状のみによって設計すればよいと考 えられる. 形状といってす, 系の巻き付けによって 巻系体の形状は随時変化するわけであるが, 設計対 象はすっとも動力を必要とする最大形の巻系体にお いて設計すればよいと考えられる。実際には，回転 円板において無限空間之密閉容器内とでは摩擦抵抗 係数は, 後者が前者の $60 \%$ まで低下させられること が知られている6).よって巻糸体についてむ,この全 体を覆うようなカバーが理想的であるが, 設置及び 糸道などの条件があるためにカバーは種々の制約を 受ける.そこで前報の断面が三角形のカバーはほと んど吹き出しをおさえているので, 動力は巻系体と カバー間のせん断力のみに失われており，これがそ れほど大きくないので, 結果として損失動力は $20 \%$ 分改善されたと思われる。

\section{5. 結 言}

1) 巻糸体の回転数や表面状態のパラメーターを
含めて, 巻系体周りの流れ場を解析することができ た.この結果によれば, 前報のパラメーターによる 流れ状態の変化は少なく, 上下部から吸い込まれた 巻系体近辺の空気は, 回転しながら中央部に集まっ てここから吹き出していた。

2) 巻系体周りの速度べクトル解析値は, 前報の 各条件下の実験結果と比較してほぼ一致した。この 結果をあとに前報に示したポンプの動力理論によ り, 巻系体回転の損失動力を求めることができた.

3 ) 流れ場解析結果から, 測定実験では容易に得 ることのできない流れ関数や渦度の等值線及び円周 方向の流れの逆流等を知ることができた。この結果 を考察して, 巻系体周りの流れ場の改善箇所が分か った.

\section{参考文献}

1）新宅ら; 織機誌, 43, T 1 (1990)

2) “機械工学便覧”, p. $8 \sim 45$, 日本機械学会 (1976)

3）林ら; “パソコンによる流れ解析”，p. 86, 朝倉書店 (19875)

4）松田ら;機械学会論文集 B，45，395，915（1979-7）

5）林ら; “パソコンによる流れ解析”， p. 85, 朝倉書店 (19875)

6) “機械工学便覧”, p. 8-15, 日本機械学会 (1976) 